\title{
COVID-19 and Its Symptoms' Panoply: A Case-Control Study of 919 Suspected Cases in Locked-Down Ovar, Portugal
}

\author{
Regina Sáa Tiago Pinho-Bandeira ${ }^{\mathrm{a}}$ Guilherme Queiroz $^{\mathrm{a}} \quad$ Joana Matos $^{\mathrm{a}}$ \\ João Duarte Ferreira ${ }^{a}$ Pedro Pereira Rodrigues ${ }^{b}$ \\ a Public Health Unit, Baixo Vouga Primary Care Cluster, Aveiro, Portugal; ${ }^{b}$ CINTESIS, Faculty of Medicine, \\ University of Porto, Porto, Portugal
}

\section{Keywords}

COVID-19 · SARS-CoV-2 · Anosmia · Primary care ·

Epidemiology

\begin{abstract}
Background: Ovar was the first Portuguese municipality to declare active community transmission of SARS-CoV-2, with total lockdown decreed on March 17, 2020. This context provided conditions for a large-scale testing strategy, allowing a referral system considering other symptoms besides the ones that were part of the case definition (fever, cough, and dyspnea). This study aims to identify other symptoms associated with COVID-19 since it may clarify the pre-test probability of the occurrence of the disease. Methods: This case-control study uses primary care registers between March 29 and May 10, 2020 in Ovar municipality. Pre-test clinical and exposure-risk characteristics, reported by physicians, were collected through a form, and linked with their laboratory result. Results: The study population included a total of 919 patients, of whom 226 (24.6\%) were COVID-19 cases and 693 were negative for SARS-CoV-2. Only $27.1 \%$ of the patients reporting contact with a confirmed or suspected case tested positive. In the multivariate analysis, statistical significance
\end{abstract}

karger@karger.com www.karger.com/pjp

Karger"

GOPEN ACCESS
(C) 2021 The Author(s). Published by S. Karger AG, Basel on behalf of NOVA National School of Public Health

This is an Open Access article licensed under the Creative Commons Attribution-NonCommercial-4.0 International License (CC BY-NC) (http://www.karger.com/Services/OpenAccessLicense), applicable to the online version of the article only. Usage and distribution for commercial purposes requires written permission. was obtained for headaches (OR 0.558), odynophagia (OR 0.273), anosmia (OR 2.360), and other symptoms (OR 2.157). The interaction of anosmia and odynophagia appeared as possibly relevant with a borderline statistically significant OR of 3.375. Conclusion: COVID-19 has a wide range of symptoms. Of the myriad described, the present study highlights anosmia itself and calls for additional studies on the interaction between anosmia and odynophagia. Headaches and odynophagia by themselves are not associated with an increased risk for the disease. These findings may help clinicians in deciding when to test, especially when other diseases with similar symptoms are more prevalent, namely in winter.

(c) 2021 The Author(s). Published by S. Karger AG, Basel on behalf of NOVA National School of Public Health

COVID-19 e a sua panóplia de sintomas: um estudo caso-controlo de 919 casos suspeitos durante o cordão sanitário de Ovar, Portugal

\section{Palavras Chave}

COVID-19 · SARS-CoV-2 · Anosmia · Cuidados de saúde primários · Epidemiologia
Regina Sá or Tiago Pinho-Bandeira

Public Health Unit, Baixo Vouga Primary Care Cluster Av. Dr. Lourenço Peixinho, 42, $4^{\circ}$

PT-3804-502 Aveiro (Portugal)

arsa3@arscentro.min-saude.pt or tpbandeira@ arscentro.min-saude.pt 


\section{Resumo}

Introdução: Ovar foi o primeiro município português a declarar transmissão comunitária ativa de SARS-CoV-2, determinando-se um cordão sanitário a 17 de março de 2020. Este contexto providenciou condições para a testagem em larga escala, permitindo um sistema de referenciação que abrangesse outros sintomas além dos que faziam parte da definição de caso (febre, tosse e dispneia). Este estudo tem como objetivo identificar outros sintomas associados à COVID-19, dado que pode esclarecer a probabilidade pré-teste de ocorrência da doença. Métodos: Este estudo caso-controlo utiliza registos dos cuidados de saúde primários entre 29 de março e 10 de maio de 2020, no município de Ovar. O quadro clínico e a exposição de risco, à apresentação, reportados por médicos através de um formulário, foram recolhidos e associados aos respetivos resultados laboratoriais. Resultados: A população do estudo incluiu um total de 919 doentes, dos quais 226 (24.6\%) eram casos confimados de COVID-19 e 693 tiveram teste negativo para SARS-CoV-2. Apenas testaram positivo $27.1 \%$ dos doentes que reportaram contacto com um caso confirmado ou suspeito. Na análise multivariável, foi obtida significância estatística para cefaleias (OR 0.558), odinofagia (OR 0.273), anosmia (OR 2.360), e outros sintomas (OR 2.157). A combinação de anosmia e odinofagia surgiu como possivelmente relevante, no limite de significância estatística, e com um OR de 3.375. Conclusão: A COVID-19 tem um amplo espetro de sintomas. De entre todos os descritos, este estudo destaca a anosmia e revela a necessidade de estudos adicionais sobre a interação entre anosmia e odinofagia. Cefaleias e odinofagia por si só não estão associadas a um risco aumentado para a doença. Estes resultados podem ajudar a decisão clínica, especialmente quando outras doenças com sintomas semelhantes são mais prevalentes, nomeadamente no inverno.

○ 2021 The Author(s) Published by S. Karger AG, Basel on behalf of NOVA National School of Public Health

\section{Background}

Following an outbreak of severe pneumonia of unknown cause in Wuhan, Hubei Province, China at the end of 2019, severe acute respiratory syndrome coronavirus 2 (SARS-CoV-2) was identified in January 2020 as the new respiratory agent responsible for the infection currently behind the coronavirus disease 2019 (COVID-19) $[1,2]$. The first 3 cases detected in Europe were reported in France on January 24, 2020 [3]. The outbreak was declared a Public Health Emergency of International Con- cern (PHEIC) on January 30, 2020, and a pandemic by the World Health Organization (WHO) on March 11, 2020 $[4,5]$. As of December 27, 2020, a total of 79,231,893 cases of COVID-19 and 1,754,574 deaths have been reported by the WHO, worldwide [6]. Europe was, for several weeks, the most severely affected region. Portugal reported its first detected cases of the disease on March 2, 2020, reaching 394,573 cases and 6,619 deaths by December 27, 2020 [7].

As clinical criteria for suspect case definition of COVID-19, the Portuguese Directorate-General of Health (DGS) included any person who developed: (a) a cough (new or worsening of the usual cough), or (b) fever (temperature of $38.0^{\circ} \mathrm{C}$ or higher), or (c) dyspnea, until November 9 , when sudden anosmia and sudden dysgeusia were added $[8,9]$.

Much evidence points to a broad spectrum of symptoms of COVID-19, including fever, cough (either with or without sputum), dyspnea, fatigue, myalgia, arthralgia, sore throat, runny nose, headache, diarrhea, nausea, vomiting, and abdominal pain [10-13]. Dermatological and neurological symptoms, mainly olfactory and gustatory dysfunction like anosmia and ageusia, began to be reported worldwide $[12,14-21]$.

Portugal has a public, national, universal, free, and general healthcare service - the Serviço Nacional de Saúde (SNS). The Public Health Units (PHU) and Family Medicine Units (FMU; general practitioners, GPs) are inserted in the Primary Care Cluster (ACES), the main provider of primary care services within the SNS. Ovar, with about 54,120 inhabitants in 2018, was the first Portuguese municipality to be declared to have active community transmission $[22,23]$. On the same day, total lockdown was decreed, lasting between March 17 and April 17, 2020. During this period only a few authorized workers and ambulances could cross the controlled borders, and all but the industry considered essential was shut down. Ovar's care system relies on: (a) a local hospital, without an emergency department or acute care service, (b) primary care units in the jurisdiction of ACES Baixo Vouga, and (c) emergency transport to other municipalities' hospitals. With the lockdown, primary care was the population's main point of entry for non-emergent acute care. A circuit was built so that any person could call a GP from the FMU or a special phone line also maintained by GPs (Ovar24). Depending on the evaluation, patients could be referred for SARS-CoV-2 testing by reverse transcription polymerase chain reaction (RT-PCR) and/or an appointment in the COVID-19 dedicated area (ADC) in the primary care center, maintained by GPs. Support was also 
granted by the local hospital in terms of collecting the specimens and sending them to an external laboratory. Since Ovar presented active community transmission, living there was immediately considered an epidemiological link. Therefore, any patient presenting symptoms from the case definition in force (fever, cough, dyspnea) should be referred to testing for SARS-CoV-2. Asymptomatic individuals could also be tested if they were part of any screening strategy or upon the decision of the GP. Unlike the rest of the country, where people depended on a validation from the DGS to approve a test for SARSCoV-2, Ovar had an independent circuit that allowed more independence on the testing criteria. This context provided conditions for a large-scale testing strategy, allowing a referral system based on other symptoms besides the ones that were part of the case definition (fever, cough, and dyspnea). The criteria for this referral system were decided by the local PHU, allowing a strategic autonomy to control the disease dissemination.

We conducted a case-control study, aiming to characterize COVID-19 presentation, including clinical and epidemiological characteristics in suspected cases of initially mild or moderate disease. Given the recent literature, we hypothesize that the symptoms associated with $\mathrm{CO}$ VID-19 are broad. Characterizing them may help clinicians to better understand the disease and make wiser decisions when it comes to testing and diagnosing, especially when the symptoms are unspecific and resemble other prevalent conditions during the winter.

\section{Methods}

\section{Study Design}

We performed a case-control study in the municipality of Ovar. We included individual patient's data on clinical and epidemiological characteristics reported from March 29 to May 8, 2020, and lab results from samples collected between March 20 and May 8, 2020. The differential between these dates is due to the fact that testing started earlier for patients sent for testing by the hospital and the PHU.

\section{Setting}

The municipality of Ovar was under lockdown between March 17 and April 17, 2020. The testing strategy described was initiated on March 20, 2020 and included 15-180 tests per day. The referral system was implemented and managed by the PHU. Sample collection of nasopharyngeal and oropharyngeal swabs was managed within the local hospital, and lab tests (RT-PCR) were performed by a group of laboratories, either private or public. The swabs were collected under the same conditions, in the same location, and by the same professionals, except when domiciliary visits were needed, for example to nursing homes.

COVID-19 and Its Symptoms' Panoply

\section{Study Population}

Any person present in the Ovar municipality from March 29 to May 8 could be enrolled, regardless of their legal status or official address. Patients who required a test during contact tracing, phone calls to Ovar24 or FMUs, or ADC visits were registered by GPs or public health physicians through an online form. Therefore, this presented a heterogeneous group of patients, with mainly mild to moderate disease. Severe cases requiring urgent or emergent care were not included since they were directly referred to hospitals outside the municipality. Due to testing availability and strategic autonomy, testing was allowed, in this context, to every patient showing symptoms described in previous literature (besides the DGS case definition) or those asymptomatic but with a high-risk contact.

We considered cases as individuals with a positive RT-PCR test for SARS-CoV-2, while controls were those with a negative result. Cases and controls belonged to a common reference population, had the same selection process, and controls would have been eligible for the case group if they had a positive RT-PCR test.

\section{Variables}

Using the physician records, we collected information regarding contact with a confirmed or suspected case of COVID-19, history of recent traveling, or being a healthcare worker as variables for epidemiological characterization. To assess the clinical presentation we included fever, cough, dyspnea, coryza, anosmia, headaches, abdominal pain, chest pain, asthenia, arthralgia, myalgia, nausea or vomits, diarrhea, irritability/confusion, lipothymia, dizziness, conjunctivitis, dermatological manifestations, and episodes of amnesia. We also collected information regarding past medical history.

\section{Data Collection}

At the time, no official software was available for physicians to prescribe tests for SARS-CoV-2 directly, and it could only be done by the DGS through an assistance line (LAM). Therefore, an online form was created by the local PHU for referral to test and/or medical appointment. These were submitted by physicians between March 29 and May 8, 2020, allowing the collection of data on clinical presentation, epidemiological link, and comorbidities. In the eventual case of duplicate requests, only the first one was considered. This was done to decrease memory bias and narrow the analysis to presenting symptoms, thereby excluding late presentations. Simultaneously, the official system for notifiable diseases (SINAVE) was still mandatory. However, due to the large number of cases it became obsolete, and clinicians underreported suspected cases through this system.

We obtained the lab results from the PHU database referent to the test results that were requested by this circuit, excluding other tests performed out of the municipality. The PHU was directly informed of the results by the hospital lab. Since the municipality was closed, only urgent cases were tested outside this circuit. For duplicated results in the same patient, we considered only the diagnostic one - the first positive or negative test - thus excluding subsequent cure tests. Inconclusive results were excluded to avoid misclassification.

Endpoints and Statistical Analysis

A confirmed case of COVID-19 was defined as a positive result on RT-PCR assay of nasopharyngeal and/or oropharyngeal swab 


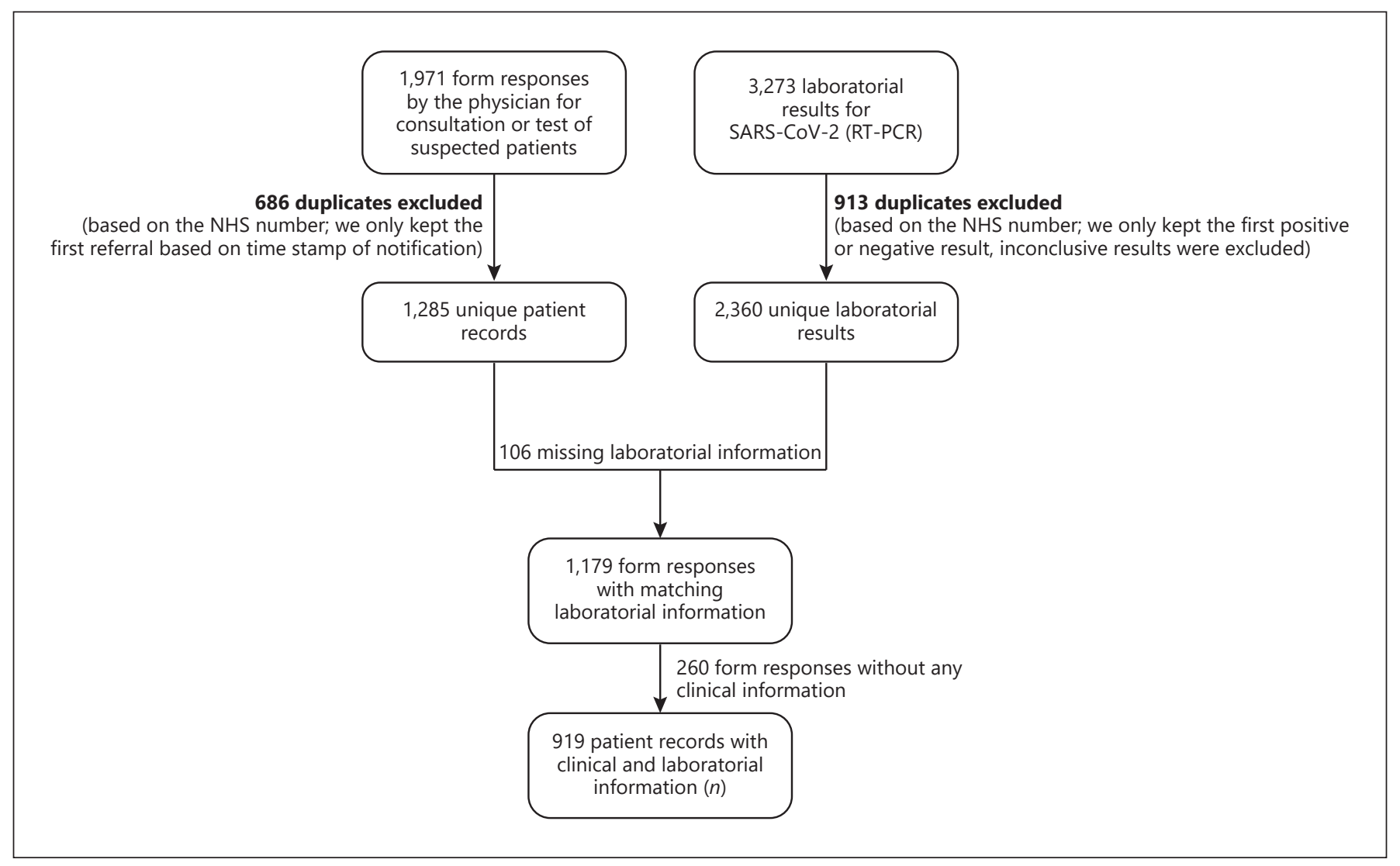

Fig. 1. Study flowchart.

specimens. We linked form responses and lab results using the unique SNS number and aggregated all the entries in a single database using Microsoft Excel ${ }^{\circledR}$ (2005 version). Patients who did not have a unique SNS number had one created administratively, which was used for linkage.

We used R Studio ${ }^{\circledR}$ using R version 3.6.2 to perform all the statistical analyses. All tests considered a statistical significance of 5\%. For the univariate analysis, we calculated the frequency of the exposure characteristics (clinical presentation, contact with a suspected or confirmed case of COVID-19, and past medical history), along with the Fisher test $p$ value to assess differences between positive and negative test results. We also calculated crude odds ratios (OR) and their 95\% confidence intervals (CI). For the multivariable analysis, we conducted logistic regressions to assess the association between the exposure and the outcome, presented by OR and 95\% CI. We used a significance level of 0.2 to add adjusting variables to the subsequent model, using a backward stepwise method. Finally, an interaction term was included in the model to test interactions between all the independent variables and the main outcome variable of interest. Missing values on lab results were excluded from the analysis. Patients who presented neither an epidemiological link nor any symptoms were considered a filling error and excluded from the analysis. Missing data in the exposure characteristics were excluded from the analysis of that specific variable.

\section{Results}

We obtained 1,971 form responses. After removing duplicates, 1,285 unique patient records remained, of which 1,179 had a matching lab result for a SARS-CoV-2 RT-PCR test. Of those, 260 were lacking any epidemiological link or any symptoms and were excluded. A total of 919 unique patient records with clinical and laboratorial information were included in the analysis, of which 226 (24.6\%) were considered COVID-19 cases and 693 (75.4\%) were controls (Fig. 1).

History of past medical conditions, like chronic diseases or pregnancy, were reported in 330 (35.9\%) patients, with arterial hypertension being the most common and reported in 149 (16.2\%) patients (Table 1). None of the studied comorbidities affected the likelihood of contracting the disease in a statistically significant way.

\section{Epidemiological Link}

Concerning epidemiological links, in total, 487 (53.0\%) patients reported a contact with a confirmed or suspected 
Table 1. Past medical history, epidemiological links, history of the present illness, and laboratory results for SARS$\mathrm{CoV}-2$

\begin{tabular}{|c|c|c|c|c|}
\hline & $\begin{array}{l}\text { Cases } \\
(n=226)\end{array}$ & $\begin{array}{l}\text { Controls } \\
(n=693)\end{array}$ & $\begin{array}{l}\text { Fisher's test } \\
p \text { value }\end{array}$ & OR (95\% CI) \\
\hline \multicolumn{5}{|l|}{ Past medical history } \\
\hline Malignancy & $9(4.0)$ & $25(3.6)$ & 0.839 & $1.108(0.448-2.500)$ \\
\hline Arterial hypertension & $44(19.5)$ & $105(15.2)$ & 0.145 & $1.353(0.894-2.025)$ \\
\hline Diabetes & $21(9.3)$ & $47(6.8)$ & 0.241 & $1.407(0.780-2.467)$ \\
\hline Dyslipidemia & $5(2.2)$ & $28(4.0)$ & 0.302 & $0.538(0.160-1.434)$ \\
\hline Asthma & $11(4.9)$ & $47(6.8)$ & 0.348 & $0.703(0.323-1.407)$ \\
\hline Chronic obstructive pulmonary disease & $0(0.0)$ & $14(2.0)$ & 0.027 & $0(0-0.915)$ \\
\hline Cardiovascular disease & $13(5.8)$ & $30(4.3)$ & 0.369 & $1.348(0.633-2.722)$ \\
\hline \multicolumn{5}{|l|}{ Epidemiological link } \\
\hline $\begin{array}{l}\text { Contact with a confirmed or suspected } \\
\text { case of COVID-19 }\end{array}$ & $132(58.4)$ & $355(51.2)$ & 0.066 & $1.337(0.976-1.834)$ \\
\hline Healthcare professional & $6(2.7)$ & $22(3.2)$ & 0.826 & $0.832(0.272-2.151)$ \\
\hline $\begin{array}{l}\text { Recent travelling (inside or outside } \\
\text { the country) }\end{array}$ & $2(0.9)$ & $19(2.7)$ & 0.127 & $0.317(0.036-1.331)$ \\
\hline \multicolumn{5}{|l|}{ History of the present illness } \\
\hline Cough & $108(47.8)$ & $375(54.1)$ & 0.107 & $0.776(0.568-1.060)$ \\
\hline Headaches & $35(15.5)$ & $172(24.8)$ & 0.003 & $0.555(0.361-0.837)$ \\
\hline Anosmia & $30(13.3)$ & $51(7.4)$ & 0.010 & $1.925(1.150-3.178)$ \\
\hline Fever & $40(17.7)$ & $121(17.5)$ & 0.920 & $1.017(0.667-1.526)$ \\
\hline Coryza & $29(12.8)$ & $97(14.0)$ & 0.739 & $0.905(0.558-1.431)$ \\
\hline Odynophagia & $17(7.1)$ & $160(23.1)$ & $<0.001$ & $0.254(0.138-0.438)$ \\
\hline Myalgias & $31(13.7)$ & $122(17.6)$ & 0.183 & $0.744(0.469-1.154)$ \\
\hline Chest pain & $23(10.2)$ & $98(14.1)$ & 0.141 & $0.688(0.405-1.128)$ \\
\hline Arthralgia & $3(1.3)$ & $10(1.4)$ & 1 & $0.919(0.161-3.611)$ \\
\hline Dyspnea & $24(10.6)$ & $87(12.6)$ & 0.482 & $0.828(0.490-1.356)$ \\
\hline Diarrhea & $16(7.1)$ & $51(7.4)$ & 1 & $0.959(0.499-1.753)$ \\
\hline Nausea or vomiting & $10(4.4)$ & $47(6.8)$ & 0.266 & $0.637(0.282-1.305)$ \\
\hline Asthenia & $32(14.2)$ & $96(13.9)$ & 0.912 & $1.026(0.644-1.602)$ \\
\hline Dizziness & $10(4.4)$ & $16(2.3)$ & 0.107 & $1.957(0.782-4.667)$ \\
\hline Other symptoms & $33(14.6)$ & $45(6.5)$ & $<0.001$ & $2.459(1.476-4.065)$ \\
\hline
\end{tabular}

Data are presented as $n(\%)$. Proportions (\%) are read in the column, using the total number of cases or controls as the denominator.

case of COVID-19, 28 (3.0\%) were healthcare professionals, and 21 (2.3\%) had history of recent travelling. Positive cases and negative controls did not show considerable differences for any of the studied exposure risk factors (Table 1).

\section{History of the Present Illness}

Regarding clinical presentation, patients reported a median of 2 symptoms (interquartile range from 1 to 3 ). The most common symptom was cough, which was present in $419(46.3 \%)$ patients, from whom 85 (20.3\%) subsequently tested positive. Positive cases were more likely to have anosmia and less likely to have headaches and odynophagia (Table 1). Anosmia revealed a low positive predictive value (37.0\%). The variable "other symptoms" was also positively associated with the disease, but since there was no open field the exact symptoms could not be determined.

\section{Multivariate Analysis}

In the multivariate analysis, using the stepwise method for the logistic regression (Table 2), statistical significance was obtained for headaches, anosmia, odynophagia, and other symptoms. The ORs were lower than 1 for headaches (OR 0.558, 95\% CI 0.366-0.852) and odynophagia (OR 0.273, 95\% CI 0.158-0.473) but higher than 1 for anosmia (OR 2.360, 95\% CI 1.428-3.902) and other symptoms (OR 2.157, 95\% CI 1.325-3.512). When adding in- 
Table 2. Multivariable-adjusted OR for the presence of a positive test for SARS-CoV-2, after backward stepwise regression

\begin{tabular}{llc}
\hline & OR $(95 \% \mathrm{CI})$ & $p$ value \\
\hline Headaches & $0.558(0.366-0.852)$ & $0.007^{* *}$ \\
Anosmia & $2.360(1.428-3.902)$ & $0.001^{* * *}$ \\
Odynophagia & $0.273(0.158-0.473)$ & $<0.001^{* * *}$ \\
Dizziness & $2.279(0.957-5.427)$ & 0.063 \\
Other symptoms & $2.157(1.325-3.512)$ & $0.002^{* *}$ \\
Arterial hypertension & $1.362(0.909-2.042)$ & 0.135 \\
\hline
\end{tabular}

Multivariate logistic (following backward stepwise) regression. Deviance residuals: min. $-1.4451 ; 1 \mathrm{Q}-0.7673$; median $-0.6314 ; 3 \mathrm{Q}$ -0.3190 ; max. 2.4509. The dispersion parameter for binomial family was taken to be $1 .{ }^{* *} p<0.01 ;{ }^{* * *} p<0.001$.

Table 3. Multivariable-adjusted OR for the presence of a positive test for SARS-CoV-2, adding interactions

\begin{tabular}{llc}
\hline & OR $(95 \% \mathrm{CI})$ & $p$ value \\
\hline Headaches & $0.513(0.329-0.801)$ & $0.003^{* *}$ \\
Anosmia & $1.931(1.110-3.357)$ & $0.020^{*}$ \\
Odynophagia & $0.205(0.105-0.400)$ & $<0.001^{* * *}$ \\
Dizziness & $1.162(0.333-4.053)$ & 0.814 \\
Other symptoms & $2.137(1.312-3.478)$ & $0.002^{* *}$ \\
Arterial hypertension & $1.360(0.906-2.040)$ & 0.138 \\
Anosmia and odynophagia & $3.375(0.931-12.240)$ & 0.064 \\
Headaches and dizziness & $4.245(0.741-24.307)$ & 0.104
\end{tabular}

Multivariate logistic (adding interactions after stepwise) regression. Deviance residuals: $\mathrm{min}$. $-1.1896 ; 1 \mathrm{Q}-0.7788$; median -0.6648 ; $3 \mathrm{Q}-0.2703$; max. 2.5797. The dispersion parameter for binomial family was taken to be $1 .{ }^{*} p<0.05$; ${ }^{* *} p<0.01$; ${ }^{* * *} p<$ 0.001 .

teractions after the stepwise model (Table 3), the interaction of anosmia and odynophagia presented an OR of $3.375(0.931-12.240)$ and was very close to being statistically significant.

\section{Discussion}

This study allowed a better understanding of the clinical and epidemiological characteristics of COVID-19, providing information on initial presentation. Our results showed that other symptoms besides fever, cough, or dyspnea are associated with the disease, which is consistent with current evidence [15-21]. Headaches and odynophagia were found to be protective factors; however, this may be due to their high frequency in many common syndromes, namely other upper respiratory airway inflammation conditions. Anosmia was associated with 2-fold increased odds of having a positive test for SARS-CoV-2. Despite presenting a positive association with the infection, anosmia revealed a low positive predictive value $(37.0 \%)$, showing that this is not a pathognomonic symptom. The variable "other symptoms" was also associated with 2 -fold increased odds of a positive test. Since there was no open field with free input in the questionnaire, it was not possible to characterize "other symptoms." Thus, there may be important symptoms that, despite not being reported in the literature yet, can be associated with COVID-19. Surprisingly, the interaction between anosmia and odynophagia was almost statistically significant as a risk factor with an OR of 3.375. The anatomical relation between the nasal and oral cavity could explain this simultaneous presentation as a reaction to upper respiratory airway infection by SARS$\mathrm{CoV}-2$.

Results for an epidemiological link showed ORs below 1 for every exposure. This does not necessarily mean that the studied exposures are protective, but that having them increases the probability of being tested, independently of the symptoms or signs. Therefore, it is possible that these patients had a less suggestive clinical presentation but were still referred to testing due to their epidemiological context.

Some limitations of this study include the fact that only primary care registers were considered, so severe disease or follow-up may be underrepresented, which could lead to overestimation of the association between milder symptoms and the outcome. Additionally, by focusing mainly on initial symptoms, the present study discards all possible subsequent symptoms that may appear later in the natural history of the disease. Only individuals who looked for a medical appointment or were contacted through contact tracing had the possibility of being referred, which may exclude asymptomatic to mild cases or people who undervalue their clinical status. Besides, as the exposure data were obtained from a different database than the outcome, we must consider a risk of unmatching data or misclassification of a follow-up test as diagnostic. This misclassification was thought to be insignificant once a local testing strategy started soon after the outbreak, and patients were tested before being followed up in hospital settings. Unmatching data were minimized with constant double checks and are assumed to be not significant. In terms of information bias in the exposure 
identification, there is the possibility of recall bias, although the period for recalling was relatively small, either for the clinical presentation (present) or for an epidemiological link (14 days). This bias should not differ between cases and controls. Furthermore, an interviewer bias may be present since the data of exposure were collected by several physicians. An outcome identification bias is possible but corresponds to the one in practice since the diagnosis of the disease was made by the gold-standard laboratory test. Considering that cases and controls belonged to a common reference population, the internal validity of case-control data is maintained.

New evidence keeps arising and it is still important to better understand the physiopathology and biological behavior of SARS-CoV-2. A full comprehension of its presentation is an essential tool for the diagnosis and subsequent isolation of cases in society, and thus for an effective control of the pandemic.

Far from the simple triad assumed before, current evidence shows that COVID-19 is a disease with a wide range of symptoms and implications. Of the myriad of symptoms described, the present study highlights anosmia itself and anosmia plus odynophagia as clinical criteria to be considered in the COVID-19 diagnosis. More studies are needed to find out if other symptoms that were not nominated in this study can also increase the odds of having COVID-19, as well as to strengthen present evidence.

By delaying the inclusion of anosmia and dysgeusia in the case definition, DGS decreased the sensitivity for COVID-19 referral to testing during that period. This might have caused important spreaders to be missed, since these symptoms are not usually debilitating, and therefore people usually remain in the community, disseminating the virus.

Although surveillance case definition is supposed to establish uniform criteria to be used for reporting a disease or condition, it is not intended to be used by health- care providers for making a clinical diagnosis. In the case of Portugal, the surveillance case definition clinical criteria limited the access to testing, and therefore compromised a definitive diagnosis.

\section{Acknowledgements}

The authors thank all members of the Public Health Unit in ACES Baixo Vouga, Public Health Department in ARS Centro, Hospital Francisco Zagalo and Câmara Municipal de Ovar, and all the healthcare workers from other departments who worked together with us and helped us serve our population in the best way possible during this pandemic.

\section{Statement of Ethics}

This study was developed under the PHU activities associated with outbreak control and management and did not require institutional research board review. Any opinions, findings, conclusions, or recommendations expressed in this material are those of the author(s) and do not necessarily reflect the views of DGS.

\section{Conflict of Interest Statement}

The authors declare that there are no potential conflicts of interest.

\section{Funding Sources}

The research was developed without any funding. This information was not previously presented in public meetings.

\section{Author Contributions}

All authors reviewed and approved the final version of the manuscript.

\section{References}

1 World Health Organization. Pneumonia of unknown cause: China [Internet]. Geneva: World Health Organization; 2020. Accessed 2 June 2020. Available from: http://www.who. int/csr/don/05-january-2020-pneumonia-ofunkown-cause-china/en/.

2 Zhu N, Zhang D, Wang W, Li X, Yang B, Song J, et al.; China Novel Coronavirus Investigating and Research Team. A novel coronavirus from patients with pneumonia in China, 2019. N Engl J Med. 2020 Feb;382(8):727-33.
3 Spiteri G, Fielding J, Diercke M, Campese C, Enouf V, Gaymard A, et al. First cases of coronavirus disease 2019 (COVID-19) in the WHO European Region, 24 January to 21 February 2020. Euro Surveill. 2020 Mar;25(9): 2000178.

4 World Health Organization. IHR Emergency Committee on Novel Coronavirus (2019. nCoV) [Internet]. Geneva: World Health Organization; 2020. Accessed 3 June 2020. Available from: https://www.who.int/dg/ speeches/detail/who-director-general-sstatement-on-ihr-emergency-committee-onnovel-coronavirus-(2019-ncov).

5 World Health Organization. WHO DirectorGeneral's opening remarks at the media briefing on COVID-19 [Internet]. Geneva: World Health Organization; 2020. Accessed 3 June 2020. Available from: https://www.who.int/ $\mathrm{dg} /$ speeches/detail/who-director-general-sopening-remarks-at-the-media-briefing-oncovid-19-11-march-2020. 
6 World Health Organization. Weekly epidemiological update 29 December 2020 [Internet]. Geneva: World Health Organization; 2020. Accessed 17 January 2021. Available from: https://www.who.int/publications/m/ item/weekly-epidemiological-update-29-december-2020.

7 Portugal. Ministério da Saúde. DGS. COVID-19: relatório de situação 27-12-2020: situação epidemiológica em Portugal [Internet]. Lisbon: Direção-Geral da Saúde; 2020. Accessed 3 June 2020. Available from: https:// covid19.min-saude.pt/wp-content/uploads/2020/12/300_DGS_boletim_20201227. pdf.

8 Portugal. Ministério da Saúde. DGS. Norma 004/2020: COVID-19: abordagem do doente com suspeita ou confirmação de COVID-19 [Internet]. Lisbon: Direção-Geral da Saúde; 2020. Accessed 3 June 2020. Available from: https://www.dgs.pt/normas-orientacoes-einformacoes/normas-e-circulares-normativas/norma-n-0042020-de-23032020-atualizada-a-141020201.aspx.

9 Portugal. Ministério da Saúde. DGS. Orientação 020/2020: COVID-19: fase de mitigação [Internet]. Lisbon: Direção-Geral da Saúde; 2020. Accessed 3 June 2020. Available from: https://www.dgs.pt/directrizes-da-dgs/orientacoes-e-circulares-informativas/orientacaon-0202020-de-03042020-pdf.aspx.

10 Wang D, Hu B, Hu C, Zhu F, Liu X, Zhang J, et al. Clinical characteristics of 138 hospitalized patients with 2019 novel coronavirus-infected pneumonia in Wuhan, China. JAMA. 2020 Mar;323(11):1061-9.
11 Guan WJ, Ni ZY, Hu Y, Liang WH, Ou CQ, He JX, et al.; China Medical Treatment Expert Group for Covid-19. Clinical characteristics of coronavirus disease 2019 in China. N Engl J Med. 2020 Apr;382(18):1708-20.

12 Baj J, Karakuła-Juchnowicz H, Teresiński G, Buszewicz G, Ciesielka M, Sitarz E, et al. COVID-19: specific and non-specific clinical manifestations and symptoms: the current state of knowledge. J Clin Med. 2020 Jun;9(6): 1753 .

13 Garg RK. Spectrum of neurological manifestations in COVID-19: a review. Neurol India. 2020 May-Jun;68(3):560-72.

14 Sachdeva M, Gianotti R, Shah M, Bradanini L, Tosi D, Veraldi S, et al. Cutaneous manifestations of COVID-19: report of three cases and a review of literature. J Dermatol Sci. 2020 May;98(2):75-81.

15 Tong JY, Wong A, Zhu D, Fastenberg JH, Tham $T$. The prevalence of olfactory and gustatory dysfunction in COVID-19 patients: a systematic review and meta-analysis. Otolaryngol Head Neck Surg. 2020 Jul;163(1):3-11.

16 Lee Y, Min P, Lee S, Kim SW. Prevalence, and duration of acute loss of smell or taste in COVID-19 patients. J Korean Med Sci. 2020 May; 35(18):e174.

17 Bénézit F, Le Turnier P, Declerck C, Paillé C, Revest M, Dubée V, et al.; RAN COVID Study Group. Utility of hyposmia and hypogeusia for the diagnosis of COVID-19. Lancet Infect Dis. 2020 Sep;20(9):1014-5.
18 Lechien JR, Chiesa-Estomba CM, De Siati DR, Horoi M, Le Bon SD, Rodriguez A, et al. Olfactory and gustatory dysfunctions as a clinical presentation of mild-to-moderate forms of the coronavirus disease (COVID-19): a multicenter European study. Eur Arch Otorhinolaryngol. 2020 Aug;277(8): 2251-61.

19 Hornuss D, Lange B, Schröter N, Rieg S, Kern WV, Wagner D. Anosmia in COVID-19 patients. Clin Microbiol Infect. 2020 Oct;26(10): 1426-7.

20 Patel A, Charani E, Ariyanayagam D, Abdulaal A, Denny SJ, Mughal N, et al. New-onset anosmia and ageusia in adult patients diagnosed with SARS-CoV-2 infection. Clin Microbiol Infect. 2020 Sep;26(9):1236-41.

21 Wong DK, Gendeh HS, Thong HK, Lum SG, Gendeh BS, Saim A, et al. A review of smell and taste dysfunction in COVID-19 patients. Med J Malaysia. 2020 Sep;75(5):574-81.

22 Instituto Nacional de Estatística. Statistics Portugal. Resident population (No.) by place of residence (Ovar, NUTS III - 2013), Annual, 2018. [Internet]. Lisbon: INE; 2020. Accessed 3 June 2020. Available from: https://www.ine. $\mathrm{pt} / \mathrm{xportal} / \mathrm{xmain}$ ?xpid=INE\&xpgid=ine_ind icadores\&contecto $=$ pi\&indOcorrCod $=00082$ $73 \&$ selTab=tab0. Accessed 3 June 2020.

23 Resolução do Conselho de Ministros No. 10D/2020. Diário da República. 56. 1 Supl. Série I (2020-03-19): 9-(2) a 9-(3). Resolution of the Council of Ministers 10-D/2020. Declara a situação de calamidade no município de Ovar, na sequência da situação epidemiológica da Covid-19. 